\title{
LDLR Chaperone MESD
}

National Cancer Institute

\section{Source}

National Cancer Institute. LDLR Chaperone MESD. NCI Thesaurus. Code C98089.

LDLR chaperone MESD (234 aa, $\sim 26 \mathrm{kDa}$ ) is encoded by the human MESD gene. This protein is involved in the folding of low-density lipoprotein receptor family proteins. 